\title{
Traumatic phacocele: a rare but unique scenario
}

\author{
Manthan Hasmukhbhai Chaniyara, Anubha Rathi, Amar Pujari, \\ Jayanand Sudhakar Urkude
}

Dr Rajendra Prasad Centre for Ophthalmic Sciences, All India Institute of Medical Sciences, New Delhi, India

\section{Correspondence to}

Dr Manthan Hasmukhbhai

Chaniyara,

dr.chaniyara@gmail.com

Accepted 5 May 2017

\section{DESCRIPTION}

The term phacocele is derived from a Greek word, where 'phaco' denotes lens and 'kele' meaning herniation. It is an unusual and very rare clinical condition. ${ }^{1}$

A 48-year-old male patient presented with sudden-onset diminution of vision, redness, pain in his left eye following blunt trauma 2 days ago. There was no significant ocular or systemic history. Visual acuity was perception of light positive with projection of rays accurate in left eye and 20/20 in right eye. On slit-lamp examination of the affected eye, there was a solid globular mass in the subconjunctival space located in the superonasal quadrant measuring $8 \times 9 \mathrm{~mm}$ with smooth surface and rounded margins. There was an area of suspected scleral dehiscence, temporal to the mass lesion with uveal show (figure 1A). There was diffuse corneal oedema with descemet's folds. Anterior chamber detail was not clearly visible because of hyphaema (figure 1B). Intraocular pressure was $4 \mathrm{~mm} \mathrm{Hg}$. B-scan ultrasonography (USG) for the posterior segment revealed dispersed haemorrhage in the anterior vitreous with absence of lens spike in the axial scan. Immersion B-scan USG of mass lesion revealed a hypoechoic lesion in the subconjunctival space with moderate internal reflectivity along with high surface reflectivity (figure 1C).

Based on the findings, a diagnosis of traumatic phacocele was made. Under general anaesthesia, scleral wound was explored and lens was delivered from the subconjunctival space followed by limited wound side vitrectomy and subsequent closer of the scleral wound with an absorbable polyglactin suture. Postoperatively at the end of 8 weeks, fundus evaluation revealed a chorioretinal macular scar along with optic atrophy because of the same visual prognosis was guarded and the patient denied any further intervention.
Traumatic phacocele usually occurs due to indirect impact on the globe following blunt trauma. The superonasal quadrant near the limbus is the most common location of phacocele. It is seen more commonly in elderly people with rigid sclera rather than in children with elastic ocular coats. Predisposing factors include previous surgical or traumatic scleral scar, recurrent episodes of scleritis, and others. ${ }^{23}$

Diagnosis is based on meticulous history and clinical examination with the added B-scan ultrasound, ultrasound biomicroscopy and MRI in selected cases. Management involves wound exploration, removal of lens, limited vitrectomy and wound repair with or without primary implantation of intraocular lens either in the anterior chamber or in the posterior chamber with intrascleral haptic fixation.

\section{Learning points}

- High index of suspicion for phacocele should be kept in mind in acute-onset subconjunctival cyst following blunt trauma.

- With the help of B-scan ultrasonography, diagnosis can be confirmed and greater anatomical details can be obtained.

- Lens extraction with meticulous repair of the scleral defect should be done as early as possible followed by visual rehabilitation at a later stage for optimal visual outcome.

Contributors MHC, AR, AP and JSU have evaluated the case in detail, followed by surgical intervention with optimal outcome. All authors have critically evaluated the case and wrote the report.

\section{Competing interests None declared.}

Patient consent Obtained.

Provenance and peer review Not commissioned; externally peer reviewed.
To cite: Chaniyara $\mathrm{MH}$ Rathi A, Pujari A, et al. BMJ Case Rep Published Online First: [please include Day Month Year]. doi:10.1136/ bcr-2017-220755

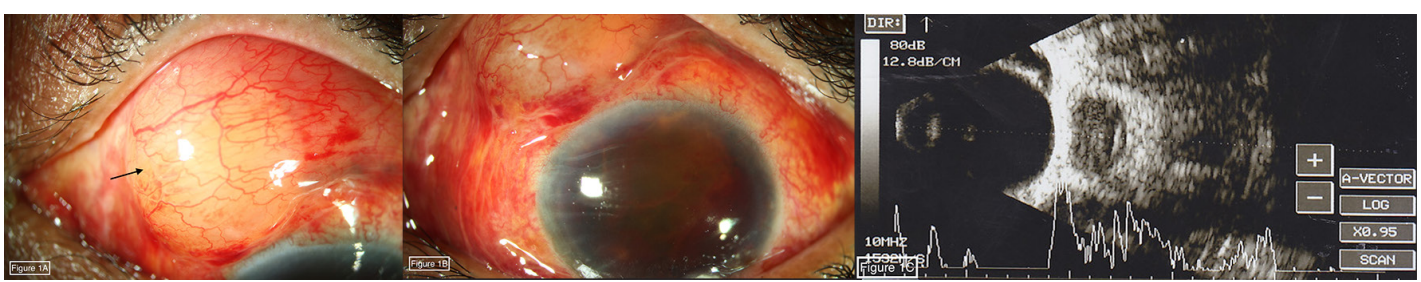

Figure 1 (A) Superior and nasal conjunctiva showed a well-defined elevated subconjunctiva (black arrow) with yellow/orange mass underneath. (B) Slit-lamp examination shows corneal oedema, hyphaema along with anterior chamber fibrinous reaction. (C) Immersion B-scan ultrasonography of mass lesion showing hypoechoic lesion in the subconjunctival space with moderate internal reflectivity along with high surface reflectivity suggestive of herniated lens. 


\section{Images in...}

(c) BMJ Publishing Group Ltd (unless otherwise stated in the text of the article) 2017. All rights reserved. No commercial use is permitted unless otherwise expressly granted.

\section{REFERENCES}

1 Allen RC, Gupta RR, Poblete R, et al. Traumatic phacocele. J Cataract Refract Surg 2001;27:1333-4
2 Santos-Bueso E, Sáenz-Francés F, Díaz-Valle D, et al. [Ocular rupture associated with lens dislocation to the subconjunctival space]. Arch Soc Esp Oftalmol 2007;82:641-4.

3 Bhattacharjee $\mathrm{K}$, Bhattacharjee $\mathrm{H}$, Deka A, et al. Traumatic phacocele: review of eight cases. Indian J Ophthalmol 2007;55:466-8.

Copyright 2017 BMJ Publishing Group. All rights reserved. For permission to reuse any of this content visit http://group.bmj.com/group/rights-licensing/permissions.

BMJ Case Report Fellows may re-use this article for personal use and teaching without any further permission.

Become a Fellow of BMJ Case Reports today and you can:

- Submit as many cases as you like

- Enjoy fast sympathetic peer review and rapid publication of accepted articles

- Access all the published articles

- Re-use any of the published material for personal use and teaching without further permission

For information on Institutional Fellowships contact consortiasales@bmjgroup.com

Visit casereports.bmj.com for more articles like this and to become a Fellow 